\title{
The Effect of Fertilization and Mycorrhiza Inoculation on Yield Variables and Essential Oil Characteristics of Salvia officinalis L. Growing in the Greenhouse and at the Field
}

\author{
Reyhan Bahtiyarca Bagdat ${ }^{\star}$, Lyle Eugene Craker, Kadriye Yuksel \\ Central Research Institute for Field Crops, Medicinal and Aromatic Plants Breeding Department, Ankara, TURKEY.
}

\begin{abstract}
Common sage (Salvia officinalis L.) is one of the most valuable commercial medicinal and aromatic plants (MAP). It has served different treatments historically in folk medicine and has always been popular to use. This research was conducted to observe the effect of mycorrhiza infection and fertilization to the biomass and quality characteristics on common sage. The optimum N, P, K dosses and their combinations (NP, NK, PK, NPK) were applied to both $+M$ (mycorrhiza infected) and $-M$ (non mycorrhiza infected) plants. The research was carried out both in the greenhouse and the plants were transferred to the field. The field trial was established in randomized block design with tree replication at ALC, UMass and three harvests were recorded at the growing season in 2014. Yield parameters showed significance between $-M$ and $+M$ applications. The essential oil contents were extracted by vapor distillation, and the major components of the essential oils were determined as camphor, $\alpha$-thujon, $\beta$-thujon, $\alpha$-humulene, viridiflorol and eucalyptol (1.8 cineole) by GC-Ms. The highest camphor was received from $P(-M)$ and PK $(+M)$ fertilization with $31.64 \%$ and $33.54 \%$. And the highest $\alpha$-thujon was recorded at PK $(-M)$ and NK $(+M)$ combinations with $27.51 \%$ and $34.24 \%$, respectively.
\end{abstract}

Keywords: Common Sage (salvia officinalis L.), Fertilization, Mycorrhiza Spp. Biomass, Essential Oil Yield, Camphor, A-Thujone.

\section{INTRODUCTION}

Salvia officinalis, Lamiaceae, known as Dalmatian Sage has been gaining popularity in every industrial sector. Wide adaptability and non-selective climatic requirements made it possible to receive high biomass and several harvests during the same plantation period. Current uses of sage include the following: indigestion, treatment of inflammation of the mouth and throat, excessive sweating, including that associated with peri-menopause; relief of pressure spots that result from the use of a prosthesis; and as a flavoring for food. Sage oil has also been employed as a fragrance in soaps and perfumes..$^{5-10-14-18,19}$ Due to global warming, more stress resistant, and drought and nutrient tolerant plant production is needed in the landscape. Therefore, the use of mycorrhiza fungi in plant production has gained importance. They are even acting to promote uptake and enhance the biomass.

The benefits of mycorrhiza can be masked by cultural conditions. ${ }^{21-24,25,26}$ The benefits are also detectable when the plants are exposed to stress conditions but they may not be applicable for all production systems or landscape situations. Certain cultivars can be more responsive to specific fungi while others may be more sensitive to fertilizer types. ${ }^{3}$ Mycorrhizal colonization frequency may change under different levels of soil fertility that may alter the net costs and
DOI: 10.5530/ijper.51.3s.44 Correspondence:

Reyhan Bahtiyarca Bagdat, Central Research Institute for Field Crops, Medicinal and Aromatic Plants, Breeding Department, Ankara, TURKEY.

Phone no:

+903123431050/1128

E-mail: reyhanbagdat@ yahoo.com 
benefits received by plant hosts. ${ }^{21-30,31,32}$ Fertilization may decrease or eliminate the net benefits that mycorrhizae provide to infected plants (manifested as increased growth and survival) because the plant's cost of carbon allocation to the fungus may not be offset by the benefits of hosting fungi when soil nutrients are less limiting to the plant. ${ }^{29-31}$ The present study was conducted both in the greenhouse (University of Massachusetts, Stockbridge Agriculture, CNS), and in the field (Agricultural Learning Center, UMass, Amherst, MA) in order to investigate the effect of mycorrhiza and various fertilization doses to the biomass, and essential oil characteristics of common sage.

\section{EXPERIMENTAL MATERIAL AND METHODS}

Common sage plants (Salvia officinalis L.) from Burpee Garden Products Co. were grown from seeds in the CNS Research \& Education Greenhouse for a $12 \mathrm{~h}$ photoperiod in $10^{\text {th }}$ February 2014. The day/night temperature was $22 / 15^{\circ} \mathrm{C}$. Sun Gro LC1 growing mix (formulated with Canadian sphagnum, peat moss, coarse pearlite, starter nutrient charge with gypsum, and dolomite limestone), was used as the growth medium throughout the course of the Greenhouse experiment. The seeds were sown in LC1 growing mix filled seed trays. 6 weeks after germination, the plants reached an optimum size of about 4-6 cm and were transplanted into 6 inch $(15.24 \mathrm{~cm})$ pots. A granular mixture of mycorrhiza fungus Glomus aggregatum, G. intraradices, G. mossae, G. etunicatum, G. monosporum, G. deserticola and Glomus clarum and some bacteria strains (B. licheniformis, B. azotoformans, B. megaterium, B. congulans, B. pumilis, B. polymyxa, Sacromyces cervisiae, Streptomyces griseous, S. lyndicus, Pseudomonas aurofaceans, P. fluorescence, $50.000 \mathrm{cfu}$ ) and trichoderma granular spores (T. koningii and T. harzianum; 187.500 spores) from Myco Maximum, Humboldt Nutrients were applied first to the trays than to the pots as a suggested dose of $4 \mathrm{oz}$ per 1.5-3 cu. $\mathrm{F} / \mathrm{t}$. of media. Nitrogen, phosphorus and potassium and their combinations (Control, N, P, K, NP, NK, PK and NPK) were applied both mycorrhiza infected and non-infected samples. N:P2O5:K2O was applied with 1:0.43:0.56 dosses to the pots. ${ }^{39}$

The study was carried out both in the Greenhouse and afterwards at the experimental field of the Agricultural Learning Center at the University of Massachusetts. The trial was established as a randomized block design with three replicates. Following observations were taken, one from the greenhouse (May $\left.2^{\text {nd }}, 2014\right)$ and two from field experiments (July $31^{\text {st }}$ and October $8^{\text {th }}$, 2014), in total, from three harvests as; plant height (cm), number of shoot, canopy width $(\mathrm{cm}), 90^{\circ}$ canopy width $(\mathrm{cm})$, fresh herb (g), dry herb (g), and leaf area index $\left(\mathrm{cm}^{2}\right)$. Essential oils were extracted by steam distillation apparatus in the laboratory of Medicinal and Aromatic Plants Program, UMass, Amherst. Essential oils were characterized by GC-MS in the Medicinal and Aromatic Plants Laboratory of Bati Akdeniz Agricultural Research Institute.

The plant samples for essential oil analyses were taken from 9 plants representing each application. Fresh material was kept to dry 3 days in a $35^{\circ} \mathrm{C}$ incubator, inside paper lunch bags. Dry leaves $(100 \mathrm{~g})$ were placed in a distillation apparatus with $2 \mathrm{~L}$ of distilled water and vapor distilled for $3 \mathrm{~h}$. Steam distillation of MAPs were recommended by several previous studies for lavender and rosemary. ${ }^{35-6-8}$ The GC/MS analysis was carried out with an Agilent 5975 GC-MS system. Innowax FSC column $(60 \mathrm{~m} \times 0.25 \mathrm{~mm}, 0.25 \mu \mathrm{m}$ film thickness) was used with helium as carrier gas $(0.8 \mathrm{~mL} / \mathrm{min}$.). The samples were diluted with hexane 1:100 and were injected into the column $(0.2 \mu \mathrm{l})$ with a split ratio of $40: 1$. The initial oven temperature of the column was $60^{\circ} \mathrm{C}$ and was raised to $220^{\circ} \mathrm{C}$ with a rate of $4^{\circ} \mathrm{C} / \mathrm{min}$ and then kept constant at $220^{\circ} \mathrm{C}$ for $10 \mathrm{~min}$. The injector temperature was at $250^{\circ} \mathrm{C}$. The total analyses duration was $60 \mathrm{~min}$ for each sample. Scanning range for the mass detector was $\mathrm{m} / \mathrm{z} 35$ to 450 and $70 \mathrm{eV}$ electron bombardment ionization was used. The components of essential oils were identified by comparison of their mass spectra with those in the Adams Library, Wiley GC/MS Library, Mass Finder Library, and confirmed by comparison of their retention indices (RRI). The results were analyzed by analyses of variance and ranged by Duncan's multiple range tests. ${ }^{1-13-27-16}$

Three soil samples were taken from the experimental field on July 22, 2014. Soil nutrient analyses were conducted in the Soil and Plant Tissue Testing Laboratory, West Experiment Station of University of Massachusetts, Amherst on July 25, 2014. The mean of P (phosphorus) value provided from experimental field was $21.3 \mathrm{ppm}$ (4-14 ppm optimum dosses) and K (potassium) $284.3 \mathrm{ppm}$ (100-160 ppm). These amounts were defined as above optimum. Only the $\mathrm{Ca}$ (calcium) amount of the soil was found lower with 557ppm (1000-1500 ppm).

\section{RESULTS AND DISCUSSIONS}

Arbuscular mycorrhizal fungi are known to play an important role in plant nutrition and biomass production in many agricultural systems. Although, it is known limited about their potential effect on secondary metabolites in medicinal and aromatic plants. ${ }^{11-22,23} \mathrm{AMF}$ symbiosis may improve nutrient uptake by improving 
the soil exploration and contributes to enhance the growth and vigor of plants. ${ }^{7}$ These interactions may be of crucial importance within sustainable, low-input agricultural cropping systems that rely on biological processes rather than agrochemicals to maintain soil fertility and plant health. ${ }^{4}$

The greenhouse experiment revealed that myco inoculated pots were recorded high fresh, dry herb and a high leaf area index considered to non myco inoculated plants as shown in Table 1. All the applications were found at the level of $1 \%$ to be statistically significant. The highest plant height was obtained from NK application with an average of $21.49 \mathrm{~cm}$ from -M application in greenhouse production. The plant height changed from $18.7 \mathrm{~cm}$ to $26.87 \mathrm{~cm}$ at $+\mathrm{M}$ applications. NPK $(26.87 \mathrm{~cm})$, NP $(26.17 \mathrm{~cm})$ and $\mathrm{N}(25.24 \mathrm{~cm})$, located among the same statistical group, giving the highest plant height at $+\mathrm{M}$ as shown at Table 1. Nitrogenous fertilization increased the plant height in both $-\mathrm{M}$ and $+\mathrm{M}$ applications. The mean number of shoots was $13.70(-\mathrm{M})$ and $13.92(+\mathrm{M})$. Although sage tends to grow upright, various applications or stress factors may let it grow horizontally. The mean canopy width ranged from $22.80 \mathrm{~cm}$ to $24.07 \mathrm{~cm}$, and from $19.23 \mathrm{~cm}$ to $22.06 \mathrm{~cm}$ respectively, measuring 90 degrees angles. The mean dry herb yield was found to be $1.82 \mathrm{~g}(-\mathrm{M})$ and $2.33 \mathrm{~g}(+\mathrm{M})$ per plant. The highest dry herb yield for $-\mathrm{M}$ was obtained from $2.79 \mathrm{~g}(\mathrm{~N})$, $2.75 \mathrm{~g}(\mathrm{NK}), 2.72 \mathrm{~g}(\mathrm{NP})$ and $2.65 \mathrm{~g}$ (NPK) applications. The highest dry weight for $+\mathrm{M}$ ranged between $3.50 \mathrm{~g}$ $(\mathrm{N})$ and $3.23 \mathrm{~g}$ (NPK). The mean leaf area index of greenhouse harvesting for $-\mathrm{M}$ was $329.57 \mathrm{~cm}^{2}$ and for $+\mathrm{M}, 418.98 \mathrm{~cm}^{2}$. As seen from Table 2. myco application enlarged the leaf area and enhanced the biomass yield.

All plants from the pots were transferred to the field of ALC at UMass in early June (June $2^{\text {nd }}, 2015$ ), by randomized block design technique with three replicate. There were three plants in each replicate, so nine plants were evaluated in each application.

The mean plant height for the field harvest was $29.40 \mathrm{~cm}$ and $29.42 \mathrm{~cm}$ in both parcels, $-\mathrm{M}$ and $+\mathrm{M}$, respectively. Although there was no significant difference regarding plant height and number of shoots, the fresh and the dry herb yield of $-\mathrm{M}$ and $+\mathrm{M}$ applicated plants were found statistically significant at the level of $1 \%$ as seen at Table 3.

Myco inoculation from field experiments; both from the second (May 6 $6^{\text {th }}, 2014$ ) and from the third yield harvests (October $8^{\text {th }}, 2014$ ), showed the promotion of yield and leaf area indexes of sage production. Except plant height and essential oil yield, all yield parameters were shown statistical significance at a level of $1 \%$ in the second harvest as seen at Table 4 . The mean fresh

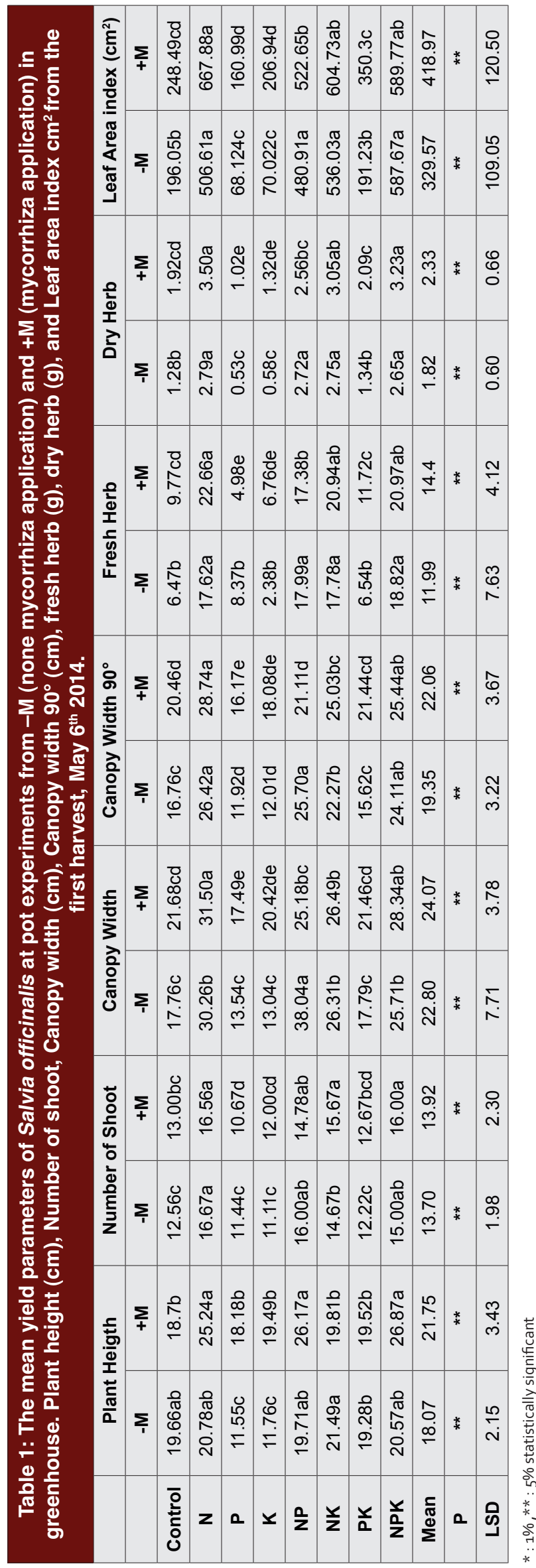



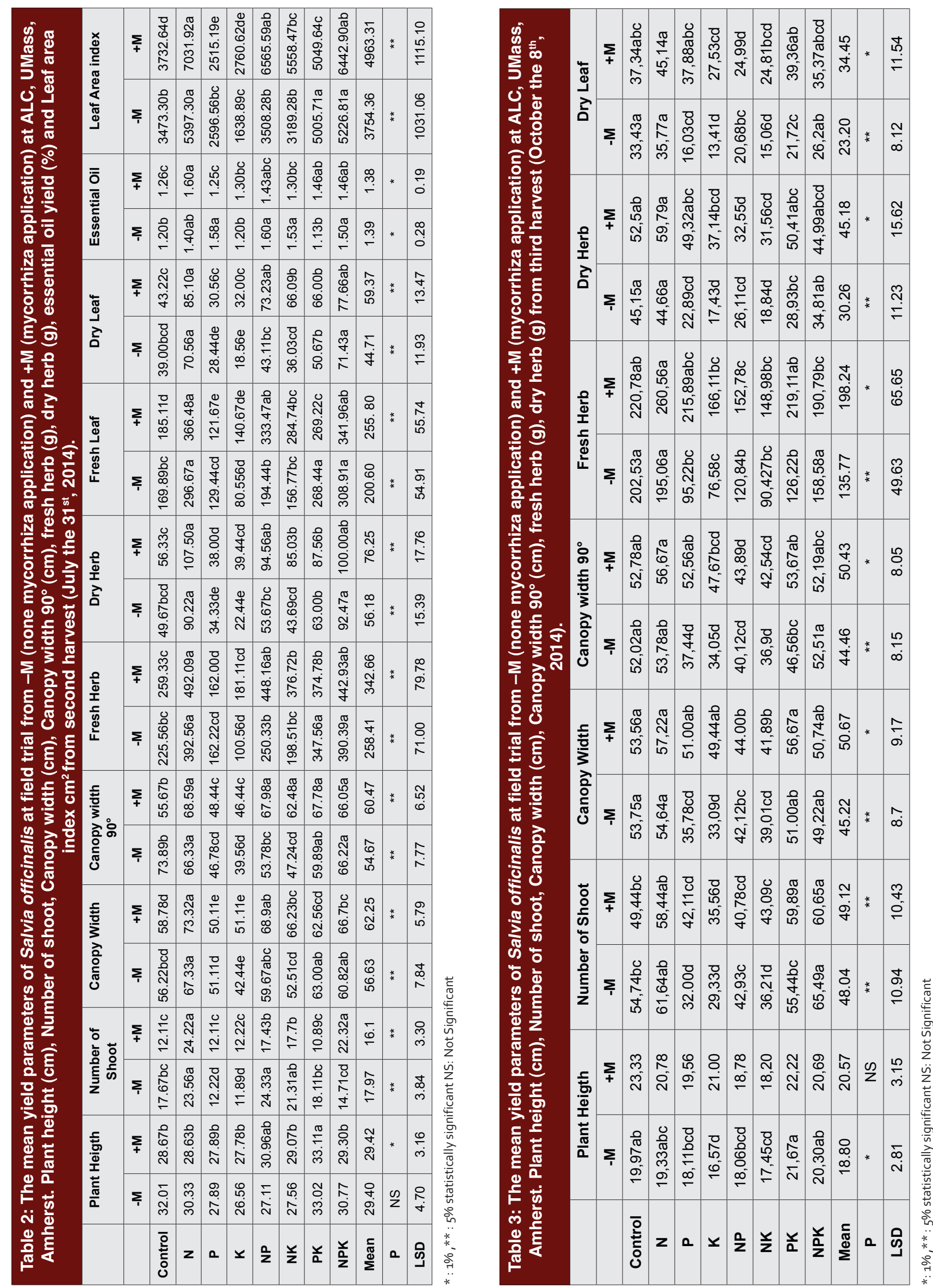


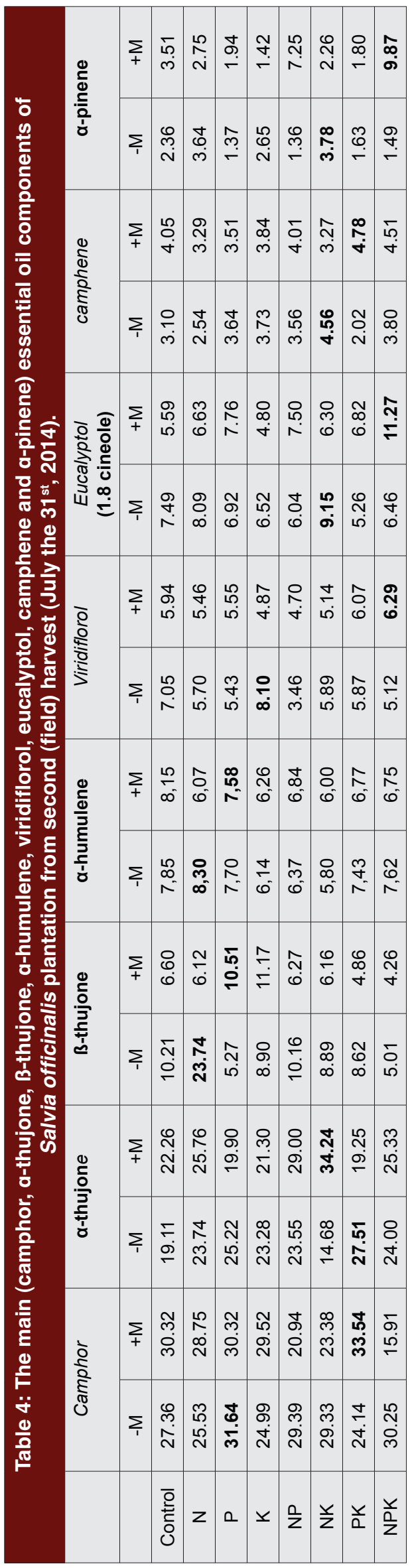

herb, dry herb yield, fresh leaf, dry leaf and leaf area indexes were recorded at non-mycorrhiza infected (-M) and mycorrhiza infected $(+\mathrm{M})$ plants as; $258.41 \mathrm{~g}$ and 342.66g; $56.18 \mathrm{~g}$ and $76.25 \mathrm{~g} ; 200.60 \mathrm{~g}$ and $255.80 \mathrm{~g}$; $44.71 \mathrm{~g}$ and $59.37 \mathrm{~g} ; 3754.36 \mathrm{~cm}^{2}$ and $4963.31 \mathrm{~cm}^{2}$ per plant, respectively. $\mathrm{N}$ fertilization both in myco $(+\mathrm{M})$ and non-myco $(-\mathrm{M})$ application gave the highest fresh and dry leaf parameters and leaf area indexes. The common point of all cuttings revealed that myco application gave positive interaction with fertilizer doses. Especially with Nitrogen and its combinations. Nitrogen fertilization enhanced the essential oil yield in both treatments and among their applications. The highest essential oil yield was obtained with $1.60 \%$ from -M NP combination and $1.60 \%$ from $+\mathrm{MN}$ combination. The mean essential oil yield was found to be $1.38 \%(-\mathrm{M})$ and $1.39 \%(+\mathrm{M})$. Although no significant differences found between the treatments $-\mathrm{M}$ and $+\mathrm{M}$, effect of fertilizer applications was significant at the $5 \%$ level.

Camphor is today mostly used in the form of inhalants and of camphorated oil, a preparation of $19 \%$ or $20 \%$ camphor in a carrier oil, for the home treatment of $\operatorname{colds}^{28}$ and as a major active ingredient of liniments and balms used as topical analgesics. ${ }^{38}$ It is familiar to many people as a principal ingredient in topical home remedies for a wide range of symptoms, and its use is well consolidated among the population of the whole world, having a long tradition of use as antiseptic, antipruritic, rubefacient, abortifacient, aphrodisiac, contraceptive and lactation suppressant. ${ }^{40}$ In the present study, the highest quantities of camphor was recorded at $\mathrm{P}(-\mathrm{M})$ and $\mathrm{PK}(+\mathrm{M})$ combinations as $31.64 \%$ and $33.54 \%$ respectively. These amounts were extremely high considered previous studies isolated from essential oil. ${ }^{9-42}$ The reason why the camphor ratio was found to be so high might be due to the first year of the plantation. According to ${ }^{12}$ the camphor content of sage leaves increases when the leaves enlarge. This increase is roughly proportional to the number of filled peltate oil glands which appear on the leaf surface during the expansion process. This, supports that immature sage leaves synthesize and accumulate camphor most rapidly. A-thujone found the other main constituent of the essential oil. In the United States, the addition of pure thujone to foods is not permitted. ${ }^{41}$ Sage and sage oil (which can be up to 50\% thujone) are on the Food and Drug Administration's list of generally recognized as safe (GRAS) substances. ${ }^{2}$ The highest $\alpha$-thujone was recorded at PK $(-\mathrm{M})$ and $\mathrm{NK}(+\mathrm{M})$ combinations with $27.51 \%$ and $34.24 \%$, respectively. Although this amount seems a high percentage, it was under the limit of given by the FDA and ISO 9909. But, according to 

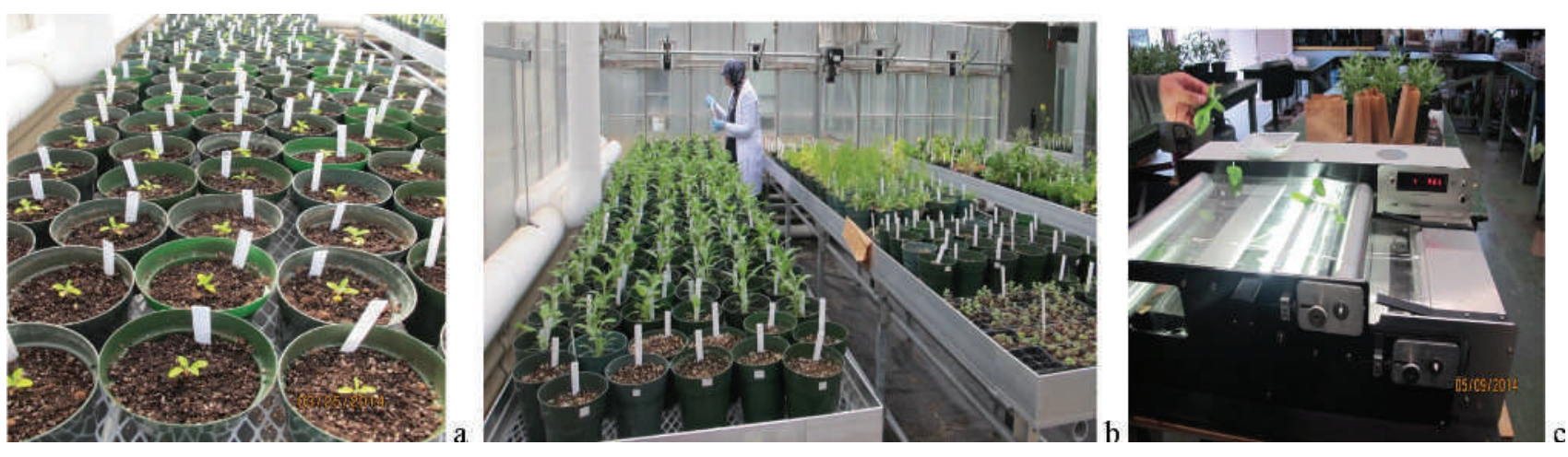

Figure 1: a. b. c. Images of Salvia officinalis during pot experiments at CNS (The College of Natural Sciences) Greenhouse (a,b) and Leaf Area Index (LAI) measurements, UMass, Amherst.
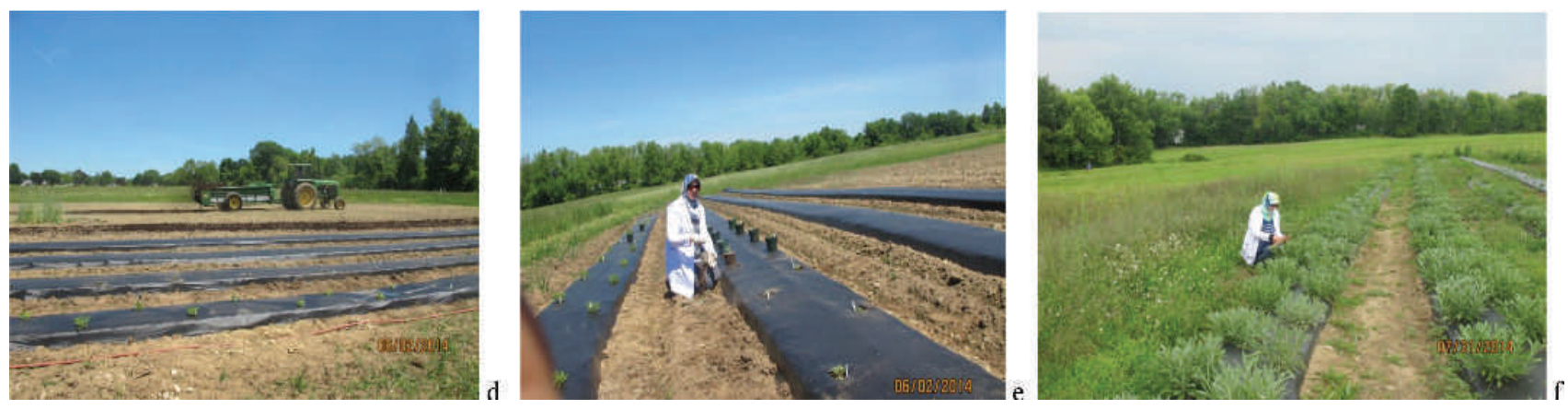

Figure 2: d,e and f. Establishing the field and transplanting the plants to the field (d,e), recording the observations (f) at ALC (Agricultural Learning Center), UMass, Amherst.

the German Drug Codex the thujones should be equal or more than $20.0 \%$ and the camphor should be around 4.5-24.5\%. ISO 9909 for medicinal uses regulates the amounts of the constituents in the sage essential oils for camphor $4.5-24.5 \%$ and $\alpha$-thujone $18.0-43.0 \% .^{33,34-36}$

\section{CONCLUSION}

Myco application gave positive interaction with fertilizer doses, especially with Nitrogen and its combinations both in the greenhouse and at the field conditions. $\mathrm{N}$ fertilization promote the biomass and enhanced the essential oil yield in both treatments $(-\mathrm{M}$ and $+\mathrm{M})$ and among their combinations.

\section{ACKNOWLEDGEMENT}

The co-author would like to thank you to IDB (Islamic Development Bank) funding this project financially. She is also thankful to Dr. Rehab Behairy and Prof. Dr. Mohamed El-Danasoury to their help during the field studies.

\section{CONFLICT OF INTEREST}

None

\section{REFERENCES}

1. Adams, RP. Identification of essential oil components by gas chromatography/ mass spectroscopy. $4^{\text {th }}$ Ed. 2007 Allured Publ. Corp. Carol Stream, IL.

2. FDA Regulation 21 CFR 172.510. Substances generally recognized as safe. Food and Drog Administration 2003. Retrieved Oct. 28. 2006.

3. Scagel, C. Mycorrhizal Fungi in Nursery Production, Facts \& Fiction 2005. http://www.ars.usda.gov/SP2UserFiles/person/4947/Presentations/Scagel MycorrhizaeOhioCents06.pdf

4. Artursson V, Finlay RD, Jansson JK. Forest Mycology interactions between arbuscular mycorrhizal fungi and bacteria and their potential for stimulating plant growth. Environmental Microbiology. 2006;8(1):1-10.

5. Barnes J, Anderson LA, Phillipson JD. Herbal Medicines: A Guide for Health Professionals. 3rd ed. London: Pharmaceutical Press. 2007;512-4.

6. Baydar H, Kineci S. Scent composition of essential oil, concrete, absolute and hydrosol from lavandin (Lavandula $x$ intermedia Emeric ex Loisel.). J. Essential oil Bearing Plants. 2009;12(2):131-6.

7. Beltrano J, Ronco MG. Improved tolerance of wheat plants (Triticum aestivum L.) to drought stress and rewatering by the arbuscular mycorrhizal fungus Glomus claroideum: Effect on growth and cell membrane stability. Brazilian Journal of Plant Physology. 2008;20(1):29-37.

8. Bentahar F, Bessiere JM, Rezzoug SA. Isolation of rosemary oils by different processes. Journal of Esssential Oil Researches. 2004;16(3):189-90.

9. Bernotiene G, Nivinskiene O, Butkiene R, Mockute D. Essential oil composition variability is sage (Salvia officinalis L.). Chemija. 2007;18(4):38-43. 
10. Blumenthal M, Goldberg A and Brinckmann J. Herbal Medicine: Expanded Commission E Monographs. Austin, TX: American Botanical Council; Newton, MA: Integrative Medicine Communications. 2000.

11. Copetta A, Lingua G, Berta G. Effects of three AM fungi on growth, distribution of glandular hairs and essential oil production in Ocimum basilicum L. var. Gevovese. Mycorrhiza. 2006;16(7):485-94.

12. Croteau R, Felton M, Karp F, Kjonaas R. Relationship of camphor biosynthesis to leaf development in sage (Salvia officinalis). Plant Physiol. 1981;67(4):820-4.

13. Davies NW. Gas chromatographic retention indexes of mono-terpenes and sesquiterpenes on methyl silicone and carbowax $20 \mathrm{M}$ phases. J. Chromatogr. 1990;503:1-24.

14. Der Marderosian A, Beutler JA. The Review of Natural Products: The Most Complete Source of Natural Product Information. 3rd ed. St. Louis, MO: Facts and Comparisons; 2002.

15. Dolan LC, Matulka RA, Burdock GA. "Naturally Occurring Food Toxins". Toxins 2. 2010;2(9):2289-332.

16. Düzgüneş $O$, Kesici T, Kavuncu $O$, Gürbüz F. Statistical Methods in Research. Journal of Ankara University Agricultural Faculty. 1987;1021, P.381

17. Wichtl M, ed. Brinckmann JA, Lindenmaier MP. Herbal Drugs and Phytopharmaceuticals. 3rd ed. Stuttgart: Medpharm GmbH Scientific Publishers; 2004.

18. Houghton PJ. Activity and constituents of sage relevant to the potential treatment of symptoms of Alzheimer's disease. Herbal Gram. 2004; 61:38.

19. Katzer G. Sage Gernot Katzer's Spice Pages. Available at: www.unigraz. at/ katzer/engl/Salv_off.html. Accessed April 4, 2005.

20. Hegde DM, Dwived BS, Sudhakara SN. Biofertilizers for cereal production in India rewiev. Indian J. Agric. Sci.1999;69(2):73-83.

21. Hetrick BAD, Wilson GWT, Owensby CE. Influence of mycorrhizal fungi and fertilization on big bluestem seedling biomass. J. Range. Manage. 1989;42(3):213-6.

22. Kaapor R, Chaudhary V, Bhatnagar A. Effects of arbuscular mycorrhiza and phosphorus application on artemisinin concentration in Artemisia annua L. Mycorrhiza. 2007;17(7):205-18.

23. Khaosaad T, Vierheiling H, Zitterl-Eqlseer K, Novak J. Arbuscular mycorrhiza alter the concentration of essential oils in oregano (Origanum sp., Lamiaceae). Mycorrhiza. 2006;16(6):p.443-6.

24. Koide RT. Nutrient supply, nutrient demand and plant response to mycorrhizal infection. New Phytol. 1991;117(3):365-86.

25. Read DJ. Mycorrhizas in ecosystems. Experientia. 1991;47(4):376-91.

26. Wilson GWT, Hartnett DC, Smith MD, Kobbeman K. Effects of mycorrhizae on growth and demography of tallgrass prairie forbs. Am. J. Bot. 2001;88(8):1452-7.
27. Jennings W, Shibamoto T. Qualitative analysis of flavor and fragrance volatiles by glass capillary chromatography. 1980.P 465 .

28. Jochen GW. Camphorated oil:still endangering the lives of Canadian children. Can Med Ass J. 1995;152(11):1821-4.

29. Johnson NC, Copeland PJ, Crookston RK, Pfleger FL. Mycorrhizae possible explanation for yield decline with continuous corn and soybean. Agron. J. 1992;84(3):387-90.

30. Johnson N. Can fertilization of soil select less mutualistic mycorrhizae? Ecol. Appl., 1993;3(4):749-57.

31. Johnson N, Graham JH, Smith FA. Functioning of mycorrhizal associations along the mutualism-parasitism continuum. New Phytol. 1997;135(4):575-85.

32. Marler MJ, Zabinski CA, Callaway RM. Mycorrhizae indirectly enhance competitive effects of an invasive forb on a native bunchgrass. Ecology. 1999;80(4):1180-6.

33. Mockute D, Nivinskiene O, Bernotiene G, Butkiene R, Chemija. The cisthujone chemotype of Salvia officinalis L. essential oils. Chemija (Vilnius). 2003;14(4):216-20.

34. Santos-Gomes C, Fernandes-Ferreira. Organ and season-dependent variation in the eaasential oil composition of Salvia officinalis L. cultivated at two different sites. J. Agric. Food Chem. 2001;49(6):2908-16.

35. Tannous P, JUliani R, Wang M, Simon S. Water balance in hydrosol production via stem distillation: case study using lavandin (Lavandula $\mathrm{x}$ intermedia). New use agriculture and natural plant products and ASNAPP Program, February 09, 2004. New Jersey, USA.

36. Teusher E. Medicinal Spices. A Hand book of Culinary Herbs, Spices, Spice Mixtures and their Essential Oils. Stuttgart, Medfarm Scientific Publishers 2006; p324.

37. Vessey JK. Plant growth promoting rhizobacteria as biofertilizers. Plant Soil. 2003;255(2):571-586.

38. $\mathrm{Xu} \mathrm{H}$, Blair NT, Clapham DE. Camphor activates and strongly desensitizes the transient receptor potential vanilloid subtype 1 channel in a vanilloidindependent mechanism. J Neurosci. 2005;25(39):8924-37.

39. Zhang W, Lu J, Jiang Z, Wang X. Effects of NPK fertilizer application and recommendation for Petunia hybrid Vilm. In pot experiments. J. Acta Metallurgica Sinica. 2009;15(5):1147-53.

40. Zuccarini P. Camphor: risks and benefits of a widely used natural product. J. Appl. Sci. Envr. Manegement. 2009;13(2):69-74.

41. Dolan LC, Matulka RA, Burdock GA. "Naturally Occurring Food Toxins". Toxins. 2010;2(9): 2289-332.

42. Baydar H, Sangun K, Erbas M, Kara SN. Comparison of Aroma Compounds in Distilled and Extracted Products of Sage (Salvia officinalis L.). TEOP. 2013;16(1):39-49.

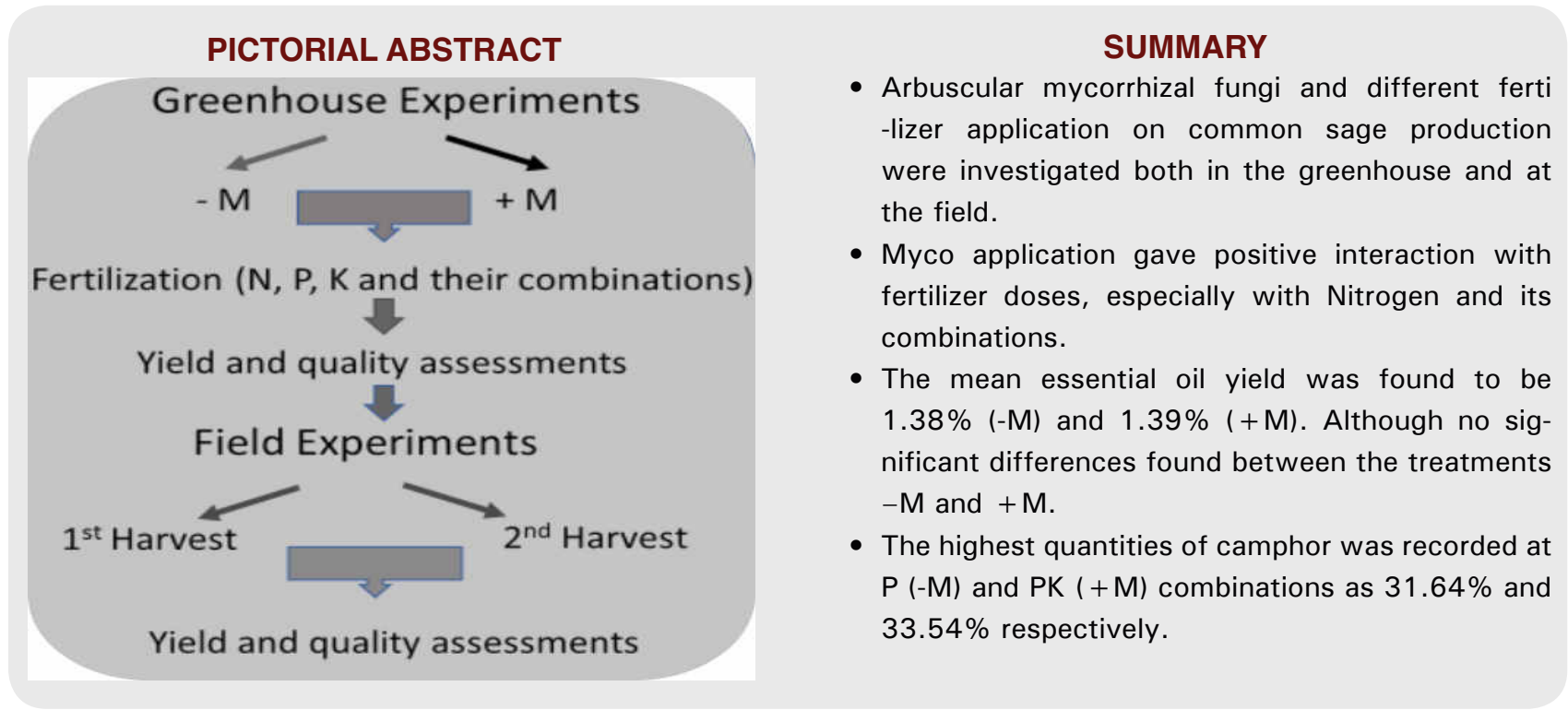




\section{ABOUT AUTHORS}

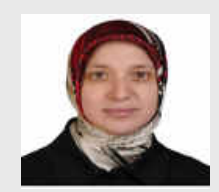

Reyhan BAHTIYARCA BAGDAT Ph.D. is a MAP (Medicinal and Aromatic Plant) breeder and agronomist. This research was her post-doctoral project at Umass. She recently focused on common sage (Salvia officinalis L.) and Origanum spp. breeding studies. MAP agro-morphological characterization is her another interest.

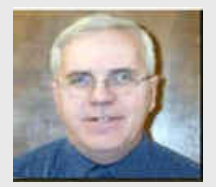

Lyle E. Craker is a Professor in the Department of Plant, Soil and Insect Sciences at the University of Massachusetts Amherst and Executive Editor of the Journal of Medicinally Active Plants. Active member of the ASHS, ISHS, American Society of Pharmacognosy, American Consortium for Medicinal and Aromatic Plants, and Sigma Xi. Honorary member of International Society for Horticultural Science (ISHS).

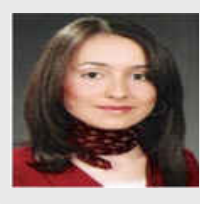

Kadriye YUKSEL MSc. is a Chemist working on determination of total phenolic and total flavonoid content of MAPs and analyse of essential oil components.

Cite this article: Bahtiyarca Bagdat R, Craker LE, Yuksel K. The Effect of Fertilization and Mycorrhiza Inoculation on Yield Variables and Essential Oil Characteristics of Salvia Officinalis I. Growing in the Greenhouse and at the Field. Indian J of Pharmaceutical Education and Research. 2017;51(3)Suppl:S341-48. 